\title{
Stem cell growth factor receptor in canine vs. feline osteosarcomas
}

\author{
BIRGITT WOLFESBERGER ${ }^{1}$, ANDREA FUCHS-BAUMGARTINGER ${ }^{2}$, JURAJ HLAVATY ${ }^{2}$, \\ FLORIAN R. MEYER ${ }^{2}$, MARTIN HOFER $^{3}$, RALF STEINBORN ${ }^{3}$, CHRISTIANE GEBHARD $^{2}$ and INGRID WALTER ${ }^{2}$ \\ Departments of ${ }^{1}$ Companion Animals and Horses and ${ }^{2}$ Pathobiology; ${ }^{3}$ Genomics Core Facility, \\ VetCore, University of Veterinary Medicine Vienna, A-1210 Vienna, Austria
}

Received April 22, 2015; Accepted July 22, 2016

DOI: $10.3892 / \mathrm{ol} .2016 .5006$

\begin{abstract}
Osteosarcoma is considered the most common bone cancer in cats and dogs, with cats having a much better prognosis than dogs, since the great majority of dogs with osteosarcoma develop distant metastases. In search of a factor possibly contributing to this disparity, the stem cell growth factor receptor KIT was targeted, and the messenger (m)RNA and protein expression levels of KIT were compared in canine vs. feline osteosarcomas, as well as in normal bone. The mRNA expression of KIT was quantified by reverse transcriptionquantitative polymerase chain reaction, and was observed to be significantly higher in canine $(\mathrm{n}=14)$ than in feline $(\mathrm{n}=5)$ osteosarcoma samples $(\mathrm{P}<0.001)$. KIT protein expression was evaluated by immunohistochemistry, which revealed that $21 \%$ of canine osteosarcoma samples did not exhibit KIT staining in their neoplastic cells, while in $14 \%$ of samples, a score of 1 $(<10 \%$ positive tumour cells) was observed, and in $50 \%$ and $14 \%$ of samples, a score of 2 (10-50\% positivity) and $3(>50 \%$ positivity), respectively, was observed. By contrast, the cancer cells of all the feline bone tumour samples analysed were entirely negative for KIT. Notably, canine and feline osteocytes of healthy bone tissue lacked any KIT expression. These results could be the first evidence that KIT may be involved in the higher aggressiveness of canine osteosarcoma compared with feline osteosarcoma.
\end{abstract}

\section{Introduction}

Osteosarcoma represents the most common malignant bone tumour in dogs and cats $(1,2)$. To date, surgical removal of the afflicted bone, if possible, is still the first-line treatment. Bitetto et al demonstrated that half of the cats with appendicular osteosarcoma treated were still alive 5 years after the amputation of the affected limb (3). The median survival of

Correspondence to: Dr Birgitt Wolfesberger, Department of Companion Animals and Horses, University of Veterinary Medicine Vienna, Veterinaerplatz 1, A-1210 Vienna, Austria

E-mail: Birgitt.Wolfesberger@vetmeduni.ac.at

Key words: dog, cat, bone tumour, KIT, immunohistochemistry, RT-qPCR the cats that succumbed to disease earlier was 4 years without any adjuvant treatment (3). In cats, metastasis due to osteosarcoma appears to be rare, with an incidence of 5-10\% (2-4). By contrast, the median survival times following the amputation of appendicular osteosarcomas in dogs were 3-5 months, which are relatively low, since dogs rapidly develop metastasis, mainly to the lungs, but also to other bones (5-7). By adding adjuvant chemotherapeutics such as carboplatin, cisplatin or doxorubicin subsequent to surgery, the median survival time of dogs was significantly prolonged to $\sim 1$ year (8-11). However, long-term survival rarely occurs, as nearly all dogs eventually succumb to their tumours due to distant metastasis (9).

At present, extensive research is being conducted aimed to identify more effective anti-tumour therapeutics than non-specific chemotherapy in hopes of better outcomes. One of the recent specifically designed therapeutic modalities are drugs targeting specific molecules, which are important for cell signaling processes in cancer cells. Lately, targeted therapy has also been included into veterinary medicine treatment protocols. Masitinib and toceranib, two oral drugs used mainly in the treatment of canine mast cell tumours, inhibit multiple receptor tyrosine kinases, targeting therefore key factors involved in tumour cell growth and survival. Masitinib targets the platelet-derived growth factor receptors (PDGFR)- $\alpha$ and $-\beta$, while toceranib targets vascular endothelial growth factor receptor- 2 and PDGFR- $\beta$. Both drugs are also able to inhibit the stem cell growth factor receptor $\operatorname{KIT}(12,13)$.

The proto-oncogene KIT appears to play a role in physiological processes, including hematopoiesis, fertility, pigmentation and gut motility. In addition, it appears to be involved in pathological conditions such as allergic diseases and cancer (14). KIT signaling has been discussed to be associated with human gastrointestinal stromal tumours, testicular neoplasias, lung cancer, acute myeloid leukemia and mastocytosis (15-19). In veterinary medicine, the role of KIT in oncogenesis has been examined most thoroughly in canine mast cell tumours $(20,21)$.

At present, no data exist about the KIT status in canine or feline osteosarcomas. The aim of the present study was to identify differences in KIT expression between osteosarcoma tissue and normal healthy bone that could indicate that KIT potentially is a molecular target in this type of cancer. Additionally, the present study aimed to assess whether there was a different KIT expression pattern between the tumours of dogs and cats, as there is such a disparity in their clinical course. 


\section{Materials and methods}

Samples. Osteosarcoma tumour samples and normal bone tissues from dogs and cats were collected between January 2008 and February 2013 following limb amputation, or from euthanized patients according to the rules of the local ethics committee at the Clinic of Surgery for Small Animals of the University of Veterinary Medicine Vienna (Vienna, Austria). The study was performed in accordance with the requirements of the Austrian Act on Animal Experiments (Tierversuchsgesetz 2012 - TVG 2012, BGBl.I Nr. 114/2012) and Good Scientific Practice adopted by the University of Veterinary Medicine Vienna. The samples were either fixed in $4 \%$ buffered formaldehyde and paraffin embedded, or preserved in RNAlater ${ }^{\circledR}$ (Thermo Fisher Scientific, Inc., Waltham, MA, USA), and stored in temperature-controlled containers in the gas phase over liquid nitrogen $\left(-170^{\circ} \mathrm{C}\right)$. For routine analysis, tumour diagnostic samples were stained with hematoxylin and eosin, sub-classified (22) according to the World Health Organization criteria and graded (23).

RNA isolation. KIT messenger (m)RNA expression was analysed in 14 canine and 5 feline osteosarcoma samples. Cerebellar tissue of the respective species was used as positive control. A total of $20 \mathrm{mg}$ of osteosarcoma or cerebellum was transferred to a 2-ml screw-cap microtube pre-filled with $1.4 \mathrm{~mm}$ Precellys ${ }^{\circledR}$ ceramic beads (PEQLAB GmbH; VWR International, Radnor, PA, USA) and $300 \mu 1$ lysis buffer RLT provided in the RNeasy ${ }^{\circledR}$ Fibrous Tissue Mini kit (Qiagen GmbH, Hilden, Germany) or $300 \mu$ l QIAzol (miRNeasy ${ }^{\circledR}$ Mini kit; Qiagen GmbH). Samples were homogenised twice for $20 \mathrm{sec}$ in a MagNA Lyser Instrument (Roche Diagnostics, Basel, Switzerland) at 5,635 x g. RNA was isolated according to the respective protocol provided by the manufacturer, with the exception that the eluate of the first elution step was used for re-elution of the RNA in order to maximize the RNA recovery. The concentration and integrity of the RNA were assessed on a 2100 Bioanalyzer (Agilent Technologies, Inc., Santa Clara, CA, USA) using the RNA 6000 Nano kit (Agilent Technologies, Inc.). RNA integrity number (RIN) values were calculated with the 2100 Expert Software (version B.02.03.SI307; Agilent Technologies, Inc.). A RIN of 6.5 was considered as the lower limit of RNA integrity.

Reverse transcription quantitative-polymerase chain reaction (RT-qPCR). Total cellular RNA was reverse transcribed into complementary (c)DNA using the Transcriptor First Strand cDNA Synthesis kit (Roche Diagnostics) or the High-Capacity cDNA Reverse Transcription kit (Thermo Fisher Scientific, Inc.). In case of the former kit from Roche Diagnostics, $500 \mathrm{ng}$ total RNA was mixed with $2 \mu 1$ random hexamer primer $(600 \mu \mathrm{M})$ to a final reaction volume of $13 \mu \mathrm{l}$ and heated at $65^{\circ} \mathrm{C}$ for $10 \mathrm{~min}$. Next, the RT Master Mix, consisting of $4 \mu 15 \mathrm{X}$ Transcriptor RT reaction buffer, $2 \mu \mathrm{l}$ deoxynucleotide (dNTP) mix (containing $10 \mathrm{mM}$ each dNTP), $0.5 \mu$ l Protector RNase Inhibitor (40 U/ $\mu$ l; Sigma-Aldrich; Merck Millipore, Darmstadt, Germany) and $0.5 \mu 1$ Transcriptor Reverse Transcriptase $(20 \mathrm{U} / \mu \mathrm{l})$, was added. The reaction was incubated at $25^{\circ} \mathrm{C}$ for $10 \mathrm{~min}$, followed by $55^{\circ} \mathrm{C}$ for $55 \mathrm{~min}$, and terminated at $85^{\circ} \mathrm{C}$ for $5 \mathrm{~min}$. In case of the kit provided by Thermo Fisher Scientific, Inc., $500 \mathrm{ng}$ RNA in $10 \mu \mathrm{l}$ RNase-free water was mixed with $2 \mu \mathrm{l}$ 10X RT Buffer, $0.8 \mu 1$ 25X dNTP Mix (100 mM each dNTP),
$2 \mu 1$ 10X RT Random Primers, 4.2 $\mu$ l RNase-free water and 50 U MultiScribe Reverse Transcriptase. Upon pre-annealing at $25^{\circ} \mathrm{C}$ for $10 \mathrm{~min}$, the RT reaction was performed for $2 \mathrm{~h}$ at $37^{\circ} \mathrm{C}$ and stopped by incubation at $85^{\circ} \mathrm{C}$ for $5 \mathrm{sec}$. Experimental cDNAs were reverse transcribed in duplicate. Absence of DNA contamination was concluded from several controls lacking reverse transcriptase using pooled experimental RNAs.

For normalisation of the RT-qPCR data of KIT, a normalisation factor (the geometric mean) was calculated from two reference genes, one of which was selected on the basis of stable gene dosage and expression in the context of canine osteosarcoma [canine chromosome 26 open reading frame, human C12orf43 (Canis lupus familiaris); C26H12orf43 and its feline orthologue chromosome D3 open reading frame, human C12orf43 (domestic cat); CD3H12orf43] and the other was a 'universal' reference gene (ornithine decarboxylase antizyme 1; OAZ1) (24-26), which has been identified as being universally applicable for RT-qPCR normalisation based on a previous meta-analysis of human and murine expression data obtained from various biological conditions, including several cancer types (25).

The 15- $\mu 1$ 'upstream' qPCR assay targeting exons 3-4 of KIT consisted of 1X HOT FIREPol ${ }^{\circledR}$ EvaGreen ${ }^{\circledR}$ qPCR Supermix (Solis BioDyne, Tartu, Estonia), $200 \mathrm{nM}$ each primer and $5 \mathrm{ng}$ cDNA. The $15-\mu 1$ qPCR assay for the universal reference gene OAZ1 consisted of 1X HOT FIREPol ${ }^{\circledR}$ Probe qPCR Mix Plus (Solis BioDyne), $200 \mathrm{nM}$ each primer, $200 \mathrm{nM}$ hydrolysis probe and $5 \mathrm{ng}$ cDNA. These two assays were performed on a ViiA ${ }^{\mathrm{TM}} 7$ Real-Time PCR System (Thermo Fisher Scientific, Inc.) operated by version 1.1 software. Following denaturation and activation of hot-start polymerase at $95^{\circ} \mathrm{C}$ for $12 \mathrm{~min}$, samples were amplified for 50 cycles of $95^{\circ} \mathrm{C}$ for $10 \mathrm{sec}$ and $60^{\circ} \mathrm{C}$ for $50 \mathrm{sec}$. Amplicon dissociation was assessed by increasing the temperature from 60 to $95^{\circ} \mathrm{C}$ with a ramp rate of $0.05^{\circ} \mathrm{C} / \mathrm{sec}$.

The 10- $\mu 1$ 'downstream' qPCR assay targeting exons 19-20 of KIT consisted of $1 \mathrm{X}$ reaction buffer B2 (Solis BioDyne), $3 \mathrm{mM} \mathrm{MgCl}_{2}$ (Solis BioDyne), $0.2 \mathrm{mM}$ each dNTP (Solis BioDyne), $200 \mathrm{nM}$ each primer, 0.4X EvaGreen ${ }^{\circledR}$ dye (Biotium, Inc., Hayward, CA, USA), $0.1 \mathrm{U} / \mu 1$ hot-start Taq DNA polymerase (HOT FIREPol ${ }^{\circledR}$ DNA polymerase; Solis BioDyne) and $5 \mathrm{ng}$ cDNA. Following denaturation and activation of the hot-start polymerase at $95^{\circ} \mathrm{C}$ for $15 \mathrm{~min}$, samples were amplified for 50 cycles $\left(95^{\circ} \mathrm{C}\right.$ for $15 \mathrm{sec}, 60^{\circ} \mathrm{C}$ for $40 \mathrm{sec}$ and $72^{\circ} \mathrm{C}$ for $20 \mathrm{sec}$ ). Amplicon dissociation was assessed by increasing the temperature from 60 to $95^{\circ} \mathrm{C}$ with a ramp rate of $0.03^{\circ} \mathrm{C} / \mathrm{sec}$.

The 20- $\mu \mathrm{l}$ qPCR assays for the context-specific reference gene C12orf43 consisted of 1X Premix Ex Taq (Probe qPCR; Takara Bio, Inc., Otsu, Japan), $200 \mathrm{nM}$ each primer, $200 \mathrm{nM}$ probe and $5 \mathrm{ng}$ cDNA. Following denaturation at $95^{\circ} \mathrm{C}$ for $30 \mathrm{sec}$, amplification was performed over 45 cycles consisting of $95^{\circ} \mathrm{C}$ for $5 \mathrm{sec}$ and $60^{\circ} \mathrm{C}$ for $20 \mathrm{sec}$.

The 10- $\mu 1 \mathrm{qPCR}$ for the 'universal' reference gene $O A Z 1$ included 1X reaction buffer A2 (Solis BioDyne), $2.5 \mathrm{mM}$ $\mathrm{MgCl}_{2}$ (Solis BioDyne), $0.2 \mathrm{mM}$ each dNTP (Solis BioDyne), $200 \mathrm{nM}$ each primer, $150 \mathrm{nM}$ hydrolysis probe, $0.1 \mathrm{U} / \mu 1$ hot-start Taq DNA polymerase (HOT FIREPol ${ }^{\circledR}$ DNA Polymerase; Solis BioDyne) and $5 \mathrm{ng}$ cDNA. Thermocyling was performed using the same thermal profile as aforementioned for the KIT assay, with the exception of the melting curve. 
Table I. Primer sequence of genes analysed by reverse transcription-quantitative polymerase chain reaction of canine and feline osteosarcoma RNA.

\begin{tabular}{|c|c|c|c|}
\hline Gene & Accession number & 5'-3' sequence and modification of oligonucleotide & Exons targeted \\
\hline KIT & Dog: NM_001003181 & $\begin{array}{l}\text { F: AGAAACGTGAAGCGCGAGTA } \\
\text { R: ACACAACTGGTACAGCTCTGATGG }\end{array}$ & $3-4$ \\
\hline KIT & $\begin{array}{l}\text { Dog: AF099030.1 } \\
\text { Cat: GU270865.1 }\end{array}$ & $\begin{array}{l}\text { F: GATAGCACCAATCATATTTATTCCAAC } \\
\text { R: CACGGAATTGATCCGCAC } \\
\text { R: CCACAGAATTGATCCGCAC }\end{array}$ & $19-20$ \\
\hline$O A Z 1$ & $\begin{array}{l}\text { Dog: NM_001127234.1 } \\
\text { Cat: XM_003981669.1 }\end{array}$ & $\begin{array}{l}\text { F: CGGCTGCCTCTACATCGAGA } \\
\text { R: AAGCTGAAGGTCCGGAGCAA } \\
\text { P: 6FAM-CGCCGCCCACGTCTTCATTTGC-BHQ1 }\end{array}$ & $2-4$ \\
\hline C26H12orf43 & Dog: XM_849238 & F: AATTCCGAGCCCACGTAGC & $3-4$ \\
\hline CD3H12orf43 & Cat: XM_006938527 & $\begin{array}{l}\text { R: GCTCCTTCACTACTTCTGAGATGGTA } \\
\text { P: 6FAM-CTG+CTG+GAC+AGC+TCA+ATT-BHQ1 }\end{array}$ & \\
\hline
\end{tabular}

F, forward primer; R, reverse primer; $\mathrm{P}$, probe; FAM, fluorescein amidite; BHQ1, black hole quencher $1 ;+\mathrm{A},+\mathrm{G},+\mathrm{C},+\mathrm{T}$, locked nucleic acid monomers; OAZ1, ornithine decarboxylase antizyme 1; C26H12orf43, chromosome 26 open reading frame, human C12orf43 (Canis lupus familiaris); CD3H12orf43, chromosome D3 open reading frame, human C12orf43 (domestic cat).

The oligonucleotides sequences were designed using the Primer Express Software v2.0 (Thermo Fisher Scientific, Inc.) and synthesised at Sigma-Aldrich (Merck Millipore). Their sequences are provided in Table I. The nucleotide collection of the National Center for Biotechnology Information tool Primer-Basic Local Alignment Search Tool (http://www.ncbi.nlm.nih.gov/tools/primer-blast/) limited to Canis lupus or Felis catus was used to exclude mutations in their binding sites. For the context-specific reference gene, the hydrolysis probe was modified with locked nucleic acid (LNA) bases to reach a melting temperature of $\geq 70^{\circ} \mathrm{C}$ in the LNA ${ }^{\mathrm{TM}}$ Oligo Tm Prediction tool provided by Exiqon (Vedbaek, Denmark; www.exiqon.com/ls/pages/exiqontmpredictiontool.aspx). LNA bases were inserted manually every 3 bases along the probe, avoiding the $5^{\prime}$ and $3^{\prime}$ ends, as well as the highly folded regions.

The amplification efficiency was analysed by standard curves generated from 3-7 points of 8-fold dilution series measured in duplicate or quadruplicate in cases of low numbers of target copies. Experimental samples (KIT and OAZ1) and amplicon control (C12orf43) were purified with the Hi Yield ${ }^{\circledR}$ Gel/PCR DNA Fragment Extraction kit (Süd-Laborbedarf $\mathrm{GmbH}$, Gauting, Germany), and were used as a template for the dilution series. Dilutions (4- and 8-fold) of each experimental sample were tested in the C12orf43 assay to preclude inhibition of the assays by individual samples.

Assays were performed with the liquid handling system epMotion® 5075 TMX (Eppendorf, Hamburg, Germany), while standard curves were pipetted manually. RT-qPCR was performed in a 384-well microtiter plate on the LightCycler $^{\circledR} 480$ Real-Time PCR System, with operating software version 1.5.0 (Roche Diagnostics).

For quantification cycle $(C q)$ values generated at an amplification efficiency $(\mathrm{E})$ of $<1$, the following equation:

$$
C q_{E=1}=\frac{C q \times \log _{10}(E+1)}{\log _{10}(2)}
$$

where $\mathrm{Cq}_{\mathrm{E}}$ is the uncorrected $\mathrm{Cq}$ value, was used to calculate a putative $\mathrm{Cq}$ at $\mathrm{E}=1$. Corrected $\mathrm{Cq}$ values were used to calculate the relative expression difference with the $2^{-\Delta \Delta C q}$ method (27).

The significance of the difference in relative transcript expression was assessed using the Pair Wise Fixed Reallocation Randomisation Test $^{(}{ }^{\circ}$ implemented in the Relative Expression Software Tool (28). The experimental details were compliant with the Minimum Information for Publication of Quantitative Real-Time PCR Experiments guidelines (29).

Western blot analysis. Western blot analyses were performed to test the specificity of two different anti-KIT antibodies. As established positive controls, canine and feline cerebellum tissue was homogenised in Tris-Triton $\mathrm{X}$ extraction buffer $[10 \mathrm{mM}$ Tris- $\mathrm{HCl}$ ( $\mathrm{pH} 7.5), 100 \mathrm{mM} \mathrm{NaCl}, 1 \mathrm{mM}$ ethylenediaminetetraacetic acid (EDTA), $1 \mathrm{mM}$ ethylene glycol-bis( $\beta$-aminoethyl ether)-N,N,N',N'-tetraacetic acid, 1\% Triton X-100, 10\% glycerol, $0.1 \%$ sodium dodecyl sulfate (SDS) and $0.5 \%$ sodium deoxycholate] supplemented with Protease Inhibitor Cocktail (Sigma-Aldrich; Merck Millipore). The protein content in the cell lysates was determined with the DC Protein Assay (Bio-Rad Laboratories, Inc., Hercules, CA, USA) as recommended by the manufacturer. Equal amounts of protein (30 $\mu \mathrm{g} /$ lane) were subjected to SDS-polyacrylamide gel electrophoresis (PAGE) under reducing conditions on $7.5 \%$ polyacrylamide gels. SDS-PAGE was performed according to Laemmli (30) using a Hoefer ${ }^{\mathrm{TM}}$ Mighty Small ${ }^{\mathrm{TM}}$ II Mini Vertical Electrophoresis System (Hoefer, Inc., Holliston, MA, USA). Precision Plus Protein $^{\mathrm{TM}}$ Kaleidoscope ${ }^{\mathrm{TM}}$ Prestained Protein Standards (Bio-Rad Laboratories, Inc.) and MagicMark ${ }^{\mathrm{TM}}$ XP Western Protein Standard (Invitrogen; Thermo Fisher Scientific, Inc.) were used for molecular weight calibration, and gels were stained with Coomassie Brilliant Blue. Upon separation by SDS-PAGE, the proteins were transferred onto a polyvinylidene fluoride membrane (GE Healthcare Life Sciences, Chalfont, UK) in a semi-dry blotting device (Semiphor Electrophoresis 
Blotter TE-70; Hoefer, Inc.). Western Blocking Reagent, Solution (Roche Diagnostics) was used as a blocking solution to minimise non-specific binding of the primary antibody. The membranes were incubated with antibodies against KIT [polyclonal rabbit antibody (A4502; Dako, Glostrup, Denmark; dilution 1:400) or polyclonal goat antibody (C-19; sc-168-G; Santa Cruz Biotechnology, Inc., Dallas, TX, USA; dilution 1:200, 1:600 or 1:1,000)] overnight at $4^{\circ} \mathrm{C}$. Enhanced chemiluminescence (ECL) donkey anti-rabbit IgG peroxidase-linked species-specific whole antibody (catalog no. NA934; dilution 1:5,000; GE Healthcare Life Sciences) or the rabbit anti-goat IgG (H\&L) F(ab)'2 fragment, cross-adsorbed, horseradish peroxidase (HRP)-conjugated antibody (catalog no. A24452; dilution 1:10,000; Novex; Thermo Fisher Scientific Inc.) were used as the secondary antibodies. Incubation was performed for $30 \mathrm{~min}$ at room temperature. The $\mathrm{ECL}^{\mathrm{TM}}$ Western Blotting Analysis system (GE Healthcare Life Sciences) was used for the detection of signals. For the negative controls, the primary antibodies were omitted.

Immunohistochemistry. Using immunohistochemistry, KIT protein expression was analysed in 14 canine and 5 feline osteosarcomas, as well as in 4 normal bone tissue samples. Upon formalin fixation and routine paraffin-wax embedding, $4-\mu \mathrm{m}$ sections were dewaxed and treated with $0.6 \% \mathrm{H}_{2} \mathrm{O}_{2}$ in methanol for 15 min to block endogenous peroxidase activity. Antigen retrieval was achieved using microwave heating in $0.01 \mathrm{M}$ Tris-EDTA buffer ( $\mathrm{pH}$ 9.0) three times for $5 \mathrm{~min}$ each, and proteins were then blocked with $1.5 \%$ normal goat serum (Dako) in phosphate-buffered saline (PBS) for $30 \mathrm{~min}$. A primary polyclonal rabbit anti-KIT antibody (A4502; Dako) was used at 1:400 dilution in PBS and applied overnight at $4^{\circ} \mathrm{C}$. An anti-rabbit secondary system (BrightVision Poly-HRP-Anti-Ms/Rb/Rt IgG; Immunologic, Duiven, The Netherlands) was employed for antibody detection, and for visualisation, 3,3'-diaminobenzidine (Sigma-Aldrich; Merck Millipore) in a $0.03 \% \mathrm{H}_{2} \mathrm{O}_{2}$ solution in Tris- $\mathrm{HCl}(\mathrm{pH}$ 7.4) was used. Sections were counterstained with haemalumn (Carl Roth, Karlsruhe, Germany) for 2-3 min, dehydrated and mounted with DPX Mountant (Sigma-Aldrich; Merck Millipore). The primary antibody was omitted for the negative controls, while canine and feline cerebellar tissue served as positive controls.

The slides were blindly evaluated by two observers (B.W. and I.W.). KIT receptor expression was scored as 0 for absent positive cells, 1 for $<10 \%$ positive cells, 2 for $10-50 \%$ positive cells and 3 for $>50 \%$ positive cells, at x400 magnification.

\section{Results}

$R T-q P C R$. Sufficient integrity of experimental RNAs was demonstrated by RIN values ranging from 6.6 to 10.0. Both positive controls, canine and feline cerebellum, exhibited expression of KIT mRNA. In canine osteosarcoma, KIT mRNA was 27-fold higher expressed compared with feline osteosarcoma, according to the RT-qPCR results, using a normalisation factor for normalising the transcript of interest $(\mathrm{P}<0.001 ; \Delta \mathrm{Cq}=22.50 \pm 0.95$ and $28.06 \pm 1.47$, respectively; Fig. 1).

The significance of the expression difference was confirmed by targeting an upstream part of KIT mRNA and using the universal reference gene $O A Z 1$ for normalisation. Normalising

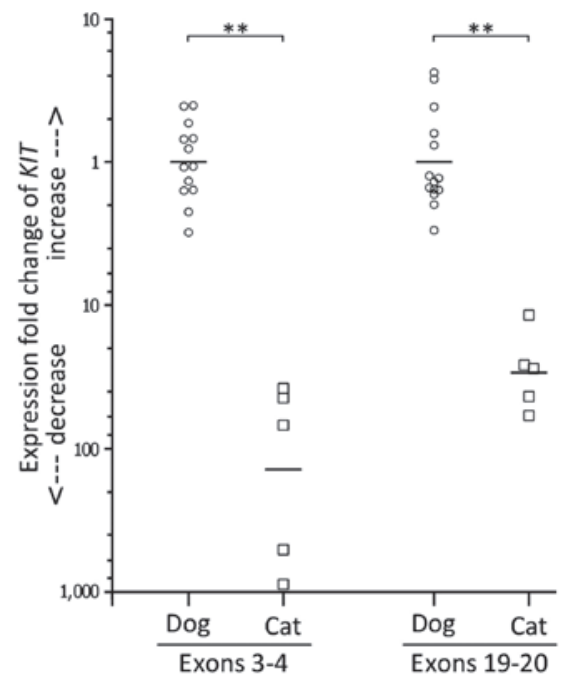

Figure 1. KIT messenger RNA expression in osteosarcomas of dogs compared with cats. The expression level of KIT was significantly higher in canine than in feline samples. Similar data were obtained from amplicons targeting the upstream region and the end of the coding region of the gene when normalisation was performed with the universal reference gene $O A Z 1$ or with a normalisation factor calculated from the geometric mean of the context-specific reference gene canine chromosome 26 open reading frame, human C12orf43 (Canis lupus familiaris) [whose feline orthologue is chromosome D3 open reading frame, human C12orf43 (domestic cat)] and OAZ1. ${ }^{* *} \mathrm{P}<0.001$. OAZ1, ornithine decarboxylase antizyme 1 .

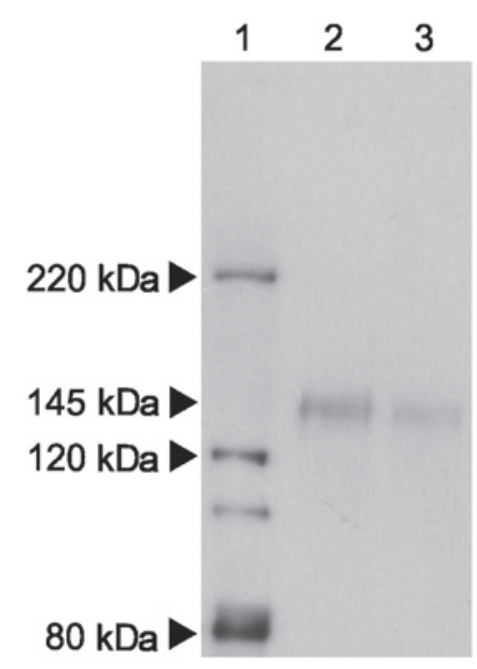

Figure 2. Evidence of KIT protein expression by western blotting. A clear band at $145 \mathrm{kDa}$ was observed. Lane 1, marker; lane 2, canine cerebellum; lane 3 , feline cerebellum.

the expression data to the quantity of cDNA template yielded similar results (data not shown).

Western blot analysis. Of the two tested antibodies, only the polyclonal rabbit antibody A4502 (Dako) displayed specificity against KIT in canine and feline cerebellar tissue, since a distinct band was observed at $145 \mathrm{kDa}$ by western blotting (Fig. 2). Although the C-19 antibody (Santa Cruz Biotechnology, Inc.) was also recommended by the supplier for detection of KIT p145 in additional species beside humans including canine, no protein expression was observed in the cerebellum of the dog or cat. 
Table II. Subtypes, localisation, grade and score of immunohistochemical staining of KIT in tumour and normal bone tissue of dogs and cats.

\begin{tabular}{|c|c|c|c|c|c|}
\hline No. & Species & Subtype/tissue & Localisation & Histological grade & KIT score \\
\hline 1 & Dog & Fibroblastic OS & Humerus & III & 0 \\
\hline 2 & Dog & Chondroblastic OS & Femur & II & 3 \\
\hline 3 & Dog & Osteoblastic OS & Radius & II & 3 \\
\hline 4 & Dog & Mixed OS & Ulna & II & 2 \\
\hline 5 & Dog & Osteoblastic OS & Tibia & III & 2 \\
\hline 6 & Dog & Osteoblastic OS & Humerus & II & 1 \\
\hline 7 & Dog & Telangiectatic OS & Lung & III & 2 \\
\hline 8 & Dog & Osteoblastic OS & Mandibula & III & 0 \\
\hline 9 & Dog & Osteoblastic OS & Tibia & II & 2 \\
\hline 10 & Dog & Osteoblastic OS & Scapula & II & 0 \\
\hline 11 & Dog & Poorly differentiated OS & Humerus & III & 1 \\
\hline 12 & Dog & Fibroblastic OS & Radius & III & 2 \\
\hline 13 & Dog & Osteoblastic OS & Femur & II & 2 \\
\hline 14 & Dog & Osteoblastic OS & Ulna & II & 2 \\
\hline 15 & Dog & Normal bone & Humerus & & 0 \\
\hline 16 & Dog & Normal bone & Radius & & 0 \\
\hline 17 & Dog & Normal bone & Rib & & 0 \\
\hline 18 & Dog & Normal bone & Femur & & 0 \\
\hline 1 & Cat & Osteoblastic OS & Humerus & II & 0 \\
\hline 2 & Cat & Fibroblastic OS & Rib & $\mathrm{I}$ & 0 \\
\hline 3 & Cat & Osteoblastic OS & Tibia & II & 0 \\
\hline 4 & Cat & Mixed OS & Humerus & II & 0 \\
\hline 5 & Cat & Fibroblastic OS & Humerus & II & 0 \\
\hline 6 & Cat & Normal bone & Femur & & 0 \\
\hline 7 & Cat & Normal bone & Radius & & 0 \\
\hline 8 & Cat & Normal bone & Radius & & 0 \\
\hline 9 & Cat & Normal bone & Femur & & 0 \\
\hline
\end{tabular}

OS, osteosarcoma; I, well differentiated; II, moderately differentiated; III poorly differentiated.

Histopathology and immunohistochemistry. Table II presents the various subtypes, localisation, grade and score of the immunohistochemical staining of KIT in 14 canine and 5 feline osteosarcomas. To compare tumour tissue vs. physiological tissue, 4 samples of normal bone of dogs and cats were also examined for KIT staining.

The osteosarcomas of dogs included grade II and grade III tumours, but no grade I tumours, whereas cats were diagnosed only with grade I or grade II bone cancer, but not with grade III. Of the canine osteosarcomas, $14 \%$ exhibited a score of 3 (>50\% positive tumour cells for KIT staining), 50\% displayed a score of 2 (10-50\% positivity), 14\% exhibited a score of 1 ( $<10 \%$ positivity) and $21 \%$ had a score of 0 (no KIT staining). In all positive slides, the staining pattern was diffuse cytoplasmic. Neoplastic cells of all feline osteosarcoma samples were negative for KIT expression. Physiological bone cells of cats and dogs did not exhibit KIT expression. In normal bone and in tumour tissue, a number of endothelial cells and bone marrow cells demonstrated KIT immunoreactivity. As positive controls, both canine and feline cerebellum exhibited strong KIT staining (Fig. 3).

\section{Discussion}

In normal cells, including mast cells, germ cells, Cajal cells, melanocytes and several hematopoietic stem cells, the stem cell growth factor receptor KIT is activated upon binding its ligand, stem cell factor (31). This results in a cell-signaling cascade that leads eventually to the activation of different transcription factors, which influence cell differentiation, cell adhesion, chemotaxis, apoptosis and proliferation. Dysregulation of KIT can therefore lead to abnormal cell proliferation as observed in cancer (31). To date, KIT expression has been detected in numerous human tumours and in certain malignancies in small animals (15-19,32-38). KIT protein expression has been demonstrated predominately in canine melanomas, canine renal cell carcinomas, canine interstitial cell tumours, canine seminomas, and in gastrointestinal stromal tumours and mast cell tumours (32-38) of dogs and cats.

The results of the present study indicate that canine osteosarcoma should be added to the list of KIT-positive malignancies, as the majority of the bone tumour samples of dogs stained positive for KIT protein in the neoplastic 

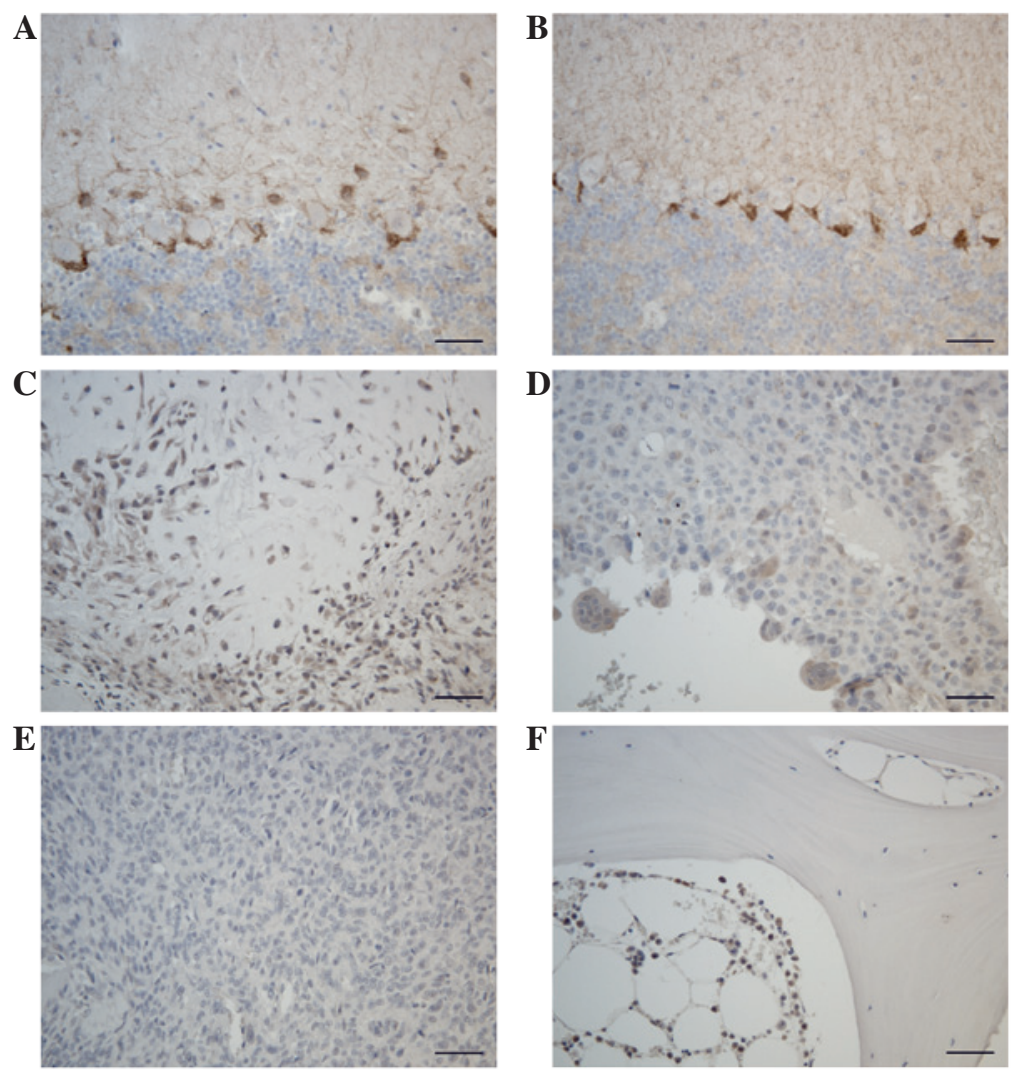

Figure 3. KIT immunohistochemical staining in healthy and tumour tissue. (A) Canine and (B) feline cerebellum served as positive controls. Strong expression of KIT was observed in the 'pinceau', which is formed by a cluster of basket cell axon terminals around the Purkinje cell body and axonal initial segment. (C) KIT protein expression score 3 (>50\% positive tumour cells) in a canine osteosarcoma sample. (D) Prominent KIT staining of giant cells in canine lung metastasis was detected. (E) No KIT expression was observed in feline osteosarcoma. (F) No KIT staining was present in the osteocytes of normal bone tissue of a cat, while numerous KIT-positive bone marrow cells were detected. Bar size, $50 \mu \mathrm{m}$.

cells. By contrast, none of the examined feline osteosarcoma samples exhibited any KIT immunostaining in the tumour cells. KIT-negative neoplasias have also been described in non-Hodgkin lymphoma, thyroid gland carcinoma, leiomyosarcoma and adrenal cortical carcinoma, but these tumour entities were negative in both dogs and cats (35).

The finding that the majority of canine osteosarcomas featured KIT expression, whereas the feline samples did not, could be based on the low numbers of feline bone tumours available for examination. However, considering the much worse prognosis of osteosarcomas in dogs compared with cats, it could indeed be possible that the expression of KIT contributes to the greater malignancy of canine osteosarcomas. This hypothesis is substantiated by the fact that no KIT expression was detected in normal bone cells of dogs or cats. Thus, it is conceivable that, in dogs, the expression of KIT may develop in the course of tumourigenesis or tumour progression.

Using a cut-off value of $10 \%$ KIT-positive tumour cells, $64 \%$ of canine osteosarcoma samples were observed to be positive for KIT, which is comparable with previous results from human patients. In human osteosarcoma samples, KIT positivity ranged from 46 to $63 \%$ (39-41). In a previous study, there was a significant correlation between the expression of KIT and poor response to chemotherapy, but there was no correlation between KIT staining and metastasis at the time of diagnosis, disease-free survival or overall survival. Thus, the authors concluded that the KIT gene is not involved in tumour progression (41). By contrast, patients with high KIT expression had a significant shorter median survival time than patients with low KIT expression in the study by Wei et al (40); therefore, KIT could be a negative prognostic marker. Thus, the clinical significance of the immunohistochemical staining of KIT in human osteosarcoma samples is still unclear, and no data exist for small animals at present.

In all the present KIT-positive canine osteosarcoma samples, the immunohistochemical staining pattern of KIT protein was always cytoplasmic, as it has been described in $100 \%$ of previously investigated human osteosarcoma samples (39-40). Upon evaluation of positive cases in children, $80 \%$ of them had cytoplasmic staining, $13 \%$ displayed membranous staining, and $7 \%$ exhibited both a cytoplasmic and membranous pattern (42). KIT is a transmembrane tyrosine kinase receptor, and the functional meaning behind the protein localisation in the cytoplasm is unknown (42). In canine cutaneous mast cell tumours, three different staining patterns of KIT have been immunohistochemically described (37). Pattern I was characterised by staining predominately of the cytoplasmic membranes; pattern II exhibited focally clustered staining or staining that was stippling throughout the cytoplasm; and pattern III displayed diffuse cytoplasmic staining. Dogs whose tumours had KIT staining pattern II or III had a higher risk of cancer recurrence and a shorter overall survival than dogs with pattern I. The authors assumed that a more aggressive behaviour was associated with an increased cytoplasmic KIT 
staining (37). This may also apply to other cancers, including osteosarcomas.

Antibodies used in immunohistochemistry must be tested for their specificity, and therefore, western blotting should be performed to determine their specificity (43). In the present study, two different antibodies against KIT (a polyclonal rabbit antibody termed A4502 from Dako and a polyclonal goat antibody termed C-19/sc-168-G from Santa Cruz Biotechnology, Inc.) were tested via western blotting. Although the antibody from Santa Cruz Biotechnology, Inc. was recommended by the supplier for the detection of KIT in canines, no bands were observed in western blots of cerebellar tissue of dogs or cats, and therefore, this antibody does not appear to be suitable for immunohistochemical studies in these species. By contrast, the aforementioned antibody from Dako has already been successfully used for immunohistochemical KIT staining in human $(39,41)$, canine $(34,44)$ and feline $(45)$ tissue. The present results obtained using the anti-KIT antibody from Dako confirmed its usability for dogs and cats, since a distinct band at the predicted size of KIT was observed in western blot analyses, and strong KIT immunohistochemical staining in canine and feline cerebellar tissue was detected. The cerebellum of dogs and cats is routinely used as a positive control in immunohistochemical KIT studies $(35,38)$. However, it is often described that the Purkinje cells of the cerebellum are positively stained (35), which is not entirely correct. In the cerebellum of adult mice, KIT protein has been described as very prominently expressed in the so called 'pinceau', which is a cluster of basket cell terminals that embrace the initial segment of the Purkinje cells (46). Such KIT-positive 'pinceau' structures were also observed in the present canine and feline cerebellum samples.

Other normal cells that exhibited KIT activity were adult bone marrow cells, which are important for hematopoiesis, and mature endothelial cells, which are able to stimulate survival, migration and tube formation $(47,48)$. In the present study, KIT immunoreactivity was observed in several endothelial cells and in bone marrow cells in normal bone, as well as in osteosarcomas of dogs and cats. These positive normal cells could explain the fact that KIT mRNA was present in all feline osteosarcoma samples, although there was no positive KIT immunostaining in feline neoplastic cells. Additionally, it is a general problem in mRNA studies that one cannot anticipate if and how much protein will be eventually produced (49). For example, short non-coding RNAs (called microRNAs) have been reported to influence gene expression by binding to mRNA transcripts, and in consequence suppressing their translation into proteins (50). However, the mean KIT mRNA content in canine osteosarcoma samples was significantly higher than in feline osteosarcomas. Thus, KIT could play a role in the greater aggressiveness of bone tumours in dogs.

Novel drugs targeting the products of oncogenes such as KIT are already on the market for veterinary medicine (51), but experience in osteosarcoma is still very limited. In vitro, the tyrosine kinase inhibitors masitinib (52) and sorafenib (53) decreased cell growth in canine osteosarcoma cell lines. An initial assessment of toceranib therapy for selected solid tumours in dogs resulted in partial remission in $4 \%$ of dogs, and in stable disease in $44 \%$ of dogs with metastatic osteosarcomas (51). Although these drugs exist, the molecules that are mostly responsible for the malignancy of canine osteosarcoma have not been identified yet. In the present study, $14 \%$ of canine osteosarcoma samples exhibited only limited immunoreactivity, with $<10 \%$ KIT-positive cancer cells being detected, and $21 \%$ demonstrated no KIT immunostaining at all in neoplastic cells. Provided that KIT plays a role in canine osteosarcoma, it is predictable that not every dog would respond to KIT-targeted therapy. In the long-term, targeted therapy will improve the fate of dogs with osteosarcoma only if the right therapeutic is used for the appropriate animal, in which specific cancer targets have been optimally verified. In consequence, it will be crucial that, in larger prospective studies, the investigation of KIT status and other possible targets in canine and feline osteosarcoma samples is implemented. The present results must be compared between these two species on a large scale, and interpreted in connection with the clinical outcome of the corresponding dogs and cats.

\section{Acknowledgements}

The authors acknowledge the excellent technical assistance of Mrs. Waltraud Tschulenk and Mrs. Claudia Höchsmann, as well as all nurses, assistants and the head (Professor Gilles Dupré) of the Clinic Unit of Small Animal Surgery University (Vienna, Austria). The present study was financially supported by a grant from the Austrian Science Fund (Vienna, Austria; grant no. $\mathrm{P}$ 23336-B11).

\section{References}

1. Priester WA and McKay FW: The occurrence of tumors in domestic animals. Natl Cancer Inst Monogr: 1-210, 1980.

2. Quigley PJ and Leedale AH: Tumors involving bone in the domestic cat: A review of fifty-eight cases. Vet Pathol 20: 670-686, 1983.

3. Bitetto WV, Patnaik AK, Schrader SC and Mooney SC: Osteosarcoma in cats: 22 cases (1974-1984). J Am Vet Med Assoc 190: 91-93, 1987.

4. Dimopoulou M, Kirpensteijn M, Moens H and Kik M: Histologic prognostic factors in feline osteosarcoma: A comparison with phenotypically similar canine osteosarcoma. Vet Surg 37: 466-471, 2008

5. MacEwan EG, Kurzman ID, Rosenthal RC, Smith BW, Manley PA, Roush JK and Howard PE: Therapy for osteosarcoma in dogs with intravenous injection of liposome-encapsulated muramyl tripeptide. J Natl Cancer Inst 81: 935-938, 1989.

6. Straw RC, Withrow SJ, Richter SL, Powers BE, Klein MK, Postorino NC, LaRue SM, Ogilvie GK, Vail DM, Morrisson WB, et al: Amputation and cisplatin for treatment of canine osteosarcoma. J Vet Intern Med 5: 205-210, 1991.

7. Spodnick GJ, Berg J, Rand WM, Schelling SH, Couto G, Harvey HJ, Henderson RA, MacEwen G, Mauldin N, McCaw DL, et al: Prognosis for dogs with appendicular osteosarcoma treated by amputation alone: 162 cases (1978-1988). J Am Vet Med Assoc 200: 995-999, 1992.

8. Kraegel SA, Madewell BR, Simonson E and Gregory CR: Osteogenic sarcoma and cisplatin chemotherapy in dogs: 16 cases (1986-1989). J Am Vet Med Assoc 199: 1057-1059, 1991.

9. Berg J, Weinstein MJ, Springfield DS and Rand WM: Results of surgery and doxorubicin chemotherapy in dogs with osteosarcoma. J Am Vet Med Assoc 206: 1555-1560, 1995.

10. Kent MS, Strom A, London CA and Seguin B: Alternating carboplatin and doxorubicin as adjunctive chemotherapy to amputation or limb-sparing surgery in the treatment of appendicular osteosarcoma in dogs. J Vet Intern Med 18: 540-544, 2004.

11. Phillips B, Powers BE, Dernell WS, Straw RC, Khanna C, Hogge GS and Vail DM: Use of single-agent carboplatin as adjuvant or neoadjuvant therapy in conjunction with amputation for appendicular osteosarcoma in dogs. J Am Anim Hosp Assoc 45: 33-38, 2009.

12. London CA, Hannah AL, Zadovoskaya R, Chien MB, Kollias-Baker C, Rosenberg M, Downing S, Post G, Boucher J, Shenoy N, et al: Phase I dose-escalating study of SU11654, a small molecule receptor tyrosinase inhibitor, in dogs with spontaneous malignancies. Clin Cancer Res 9: 2755-2768, 2003. 
13. Dubreuil P, Letard S, Ciufolini M, Gros L, Humbert M, Castéran N, Borge L, Hajem B, Lermet A, Sippl W, et al: Masitinib (AB1010), a potent and selective tyrosine kinase inhibitor targeting KIT. PLoS One 4: e7258, 2009.

14. Lennartsson J and Rönnstrand L: Stem cell factor receptor/c-Kit: From basic science to clinical implications. Physiol Rev 92: $1619-1649,2012$

15. Hirota S, Isozaki K, Moriyama Y, Hashimoto K, Nishida T, Ishiguro S, Kawano K, Hanada M, Kurata A, Takeda M, et al: Gain-of-function mutations of c-kit in human gastrointestinal stromal tumors. Science 279: 577-580, 1998.

16. Tian Q, Frierson HF Jr, Krystal GW and Moskaluk CA: Activating c-kit gene mutations in human germ cell tumors. Am J Pathol 154: 1643-1647, 1999.

17. Hida T, Ueda R, Sekido Y, Hibi K, Matsuda R, Ariyoshi Y, Suqiura T, Takahashi T and Takahashi T: Ectopic expression of c-kit in small-cell lung cancer. Int J Cancer Suppl 8: 108-109, 1994.

18. Ikeda H, Kanakura Y, Tamaki T, Kuriu A, Kitayama H, Ishikawa J, Kanayama Y, Yonezawa T, Tarui S and Griffin JD: Expression and functional role of the proto-oncogene c-kit in acute myeloblastic leukemia cells. Blood 78: 2962-2968, 1991.

19. Longley BJ, Tyrrell L, Lu SZ, Ma YS, Langley K, Ding TG, Duffy T, Jacobs P, Tang LH and Modlin I: Somatic c-KIT activating mutation in urticaria pigmentosa and aggressive mastocytosis: Establishment of clonality in a human mast cell neoplasm. Nat Genet 12: 312-314, 1996.

20. Webster JD, Yuzbasiyan-Gurkan V, Kaneene JB, Miller RA, Resau JH and Kiupel M: The role of c-kit in tumorigenesis: Evaluation in canine cutaneous mast cell tumors. Neoplasia 8: 104-111, 2006.

21. Marconato L, Zorzan E, Giantin M, Di Palma S, Cancedda S and Dacasto M: Concordance of c-kit mutational status in matched primary and metastatic cutaneous canine mast cell tumors at baseline. J Vet Intern Med 28: 547-553, 2014

22. Slayter MV, Boosinger TR, Pool RR, Dämmrich K, Misdorp W and Larsen S: Histological Classification of Bone and Joint Tumors of Domestic Animals. WHO, 2nd Edition, Vol.1, Armed Forces Inst. of Pathology, American Registry of Pathology, Washington DC, pp5-14, 1994.

23. Kirpensteijn J, Kik M, Rutteman GR and Teske E: Prognostic significance of a new histologic grading system for canine osteosarcoma. Vet Pathol 39: 240-246, 2002.

24. Tsai PC and Breen M: Array-based comparative genomic hybridization-guided identification of reference genes for normalisation of real-time quantitative polymerase chain reaction assay data for lymphomas, histiocytic sarcomas and osteosarcomas of dogs. Am J Vet Res 73: 1335-1343, 2012

25. de Jonge HJ, Fehrmann RS, de Bont ES, Hofstra RM, Gerbens F Kamps WA, de Vries EG, van der Zee AG, te Meerman GJ and ter Elst A: Evidence based selection of housekeeping genes. PLoS One 2: e898, 2007

26. Kwon MJ, Oh E, Lee S, Roh MR, Kim SE, Lee Y, Choi YL, In YH, Park T, Koh SS and Shin YK: Identification of novel reference genes using multiplatform expression data and their validation for quantitative gene expression analysis. PLoS One 4: e6162, 2009.

27. Livak KJ and Schmittgen TD: Analysis of relative gene expression data using real-time quantitative PCR and the 2(-Delta Delta C(T)) Method. Methods 25: 402-408, 2001.

28. Pfaffl MW, Horgan GW and Dempfle L: Relative expression software tool (REST) for group-wise comparison and statistical analysis of relative expression results in real-time PCR. Nucleic Acids Res 30: e36, 2002.

29. Bustin SA, Benes V, Garson JA, Hellemans J, Huggett J, Kubista M, Mueller R, Nolan T, Pfaffl MW, Shipley GL, et al: The MIQE guidelines: Minimum information for publication of quantitative real-time PCR experiments. Clin Chem 55: 611-622, 2009.

30. Laemmli UK: Cleavage of structural proteins during the assembly of the head of bacteriophage T4. Nature 227: 680-685, 1970 .

31. Miettinen M and Lasota J: KIT (CD117): A review on expression in normal and neoplastic tissues and mutations and their clinicopathologic correlation. Appl Immunohistochem Mol Morphol 13: 205-220, 2005.

32. Newman SJ, Jankovsky JM, Rohrbach BW and LeBlanc AK: C-kit expression in canine mucosal melanomas. Vet Pathol 49: 760-765, 2012

33. Gil da Costa RM, Oliveira JP, Saraiva AL, Seixas F, Faria F, Gärtner F, Pires MA and Lopes C: Immunohistochemical characterization of 13 canine renal cell carcinomas. Vet Pathol 48: 427-432, 2011
34. Grieco V, Banco B, Giudice C, Mosca F and Finazzi M Immunohistochemical expression of the KIT protein (CD117) in normal and neoplastic canine testes. J Comp Pathol 142: 213-217, 2010.

35. Morini M, Bettini G, Preziosi R and Mandrioli L: C-kit gene product (CD117) immunoreacitivity in canine and feline paraffin sections. J Histochem Cytochem 52: 705-708, 2004.

36. Hayes S, Yuzbasiyan-Gurkan V, Gregory-Bryson E and Kiupel M: Classification of canine nonangiogenic, nonlymphogenic, gastrointestinal sarcomas based on microscopic, immunohistochemical and molecular characteristics. Vet Pathol 50: 779-788, 2013.

37. Kiupel M, Webster JD, Kaneene JB, Miller $R$ and Yuzbasiyan-Gurkan V: The use of KIT and tryptase expression patterns as prognostic tools for canine cutaneous mast cell tumors. Vet Pathol 41: 371-377, 2004.

38. Rodriguez-Cariño C, Fondevila D, Segalés J and Rabanal RM: Expression of KIT receptor in feline cutaneous mast cell tumors. Vet Pathol 46: 878-883, 2009.

39. Entz-Werlé N, Marcellin L, Gaub MP, Guerin E, Schneider A, Berard-Marec P, Kalifa C, Brugiere L, Pacquement H, Schmitt C, et al: Prognostic significance of allelic imbalance at the c-kit gene locus and c-kit overexpression by immunohistochemistry in pediatric osteosarcomas. J Clin Oncol 23: 2248-2255, 2005 .

40. Wei H, Zhao MQ, Dong W, Yang Y and Li JS: Expression of c-kit protein and mutational status of the c-kit gene in osteosarcoma and their clinicopathological significance. J Int Med Res 36: 1008-1014, 2008

41. Miiji LN, Petrilli AS, Di Cesare S, Odashiro AN, Burnier MN Jr, de Toledo SR, Garcia RJ and Alves MT: C-kit expression in human osteosarcoma and in vitro assays. Int J Clin Exp Pathol 4: 775-781, 2011.

42. Smithey BE, Pappo AS and Hill DA: C-kit expression in pediatric solid tumors: A comparative immunohistochemical study. Am J Surg Pathol 26: 486-492, 2002.

43. Kurien BT, Dorri Y, Dillon S, Dsouza A and Scofield RH: An overview of Western blotting for determining antibody specificities for immunohistochemistry. Methods Mol Biol 717: 55-57, 2011

44. Bettini G, Morini M and Marcato PS: Gastrointestinal spindle cell tumours of the dog: Histological and immunohistochemical study. J Comp Pathol 129: 283-293, 2003.

45. Sabattini S and Bettini G: Prognostic value of histologic and immunohistochemical features in feline cutaneous mast cell tumors. Vet Pathol 47: 643-653, 2010.

46. Manova K, Bachvarova RF, Huang EJ, Sanchez S, Pronovost SM, Velazquez M, McGuire B and Besmer P: C-kit receptor and ligand expression in postnatal development of the mouse cerebellum suggests a function for c-kit in inhibitory interneurons. J Neurosci 12: 4663-4676, 1992

47. Ashman LK, Cambareri AC, To LB, Levinsky RJ and Juttner CA: Expression of the YB5.B8 antigen (c-kit proto-oncogene product) in normal human bone marrow. Blood 78: 30-37, 1991.

48. Matsui J, Wakabayashi T, Asada M, Yoshimatsu K and Okada M: Stem cell factor/c-kit signaling promotes the survival, migration, and capillary tube formation of human umbilical vein endothelial cells. J Biol Chem 279: 18600-18607, 2004.

49. Vogel C and Marcotte EM: Insights into the regulation of protein abundance from proteomic and transcriptomic analyses. Nat Rev Genet 13: 227-232, 2013.

50. Bentwich I, Avniel A, Karov Y, Aharonov R, Gilad S, Barad O, Barzilai A, Einat P, Einav U, Meiri E, et al: Identification of hundreds of conserved and nonconserved human microRNAs. Nat Genet 37: 766-770, 2005

51. London C, Mathie T, Stingle N, Clifford C, Haney S, Klein MK, Beaver L, Vickery K, Vail DM, Hershey B, et al: Preliminary evidence for biologic activity of toceranib phosphate (Palladia(囚)) in solid tumours. Vet Comp Oncol 10: 194-205, 2012.

52. Fahey CE, Milner RJ, Kow K, Bacon NJ and Salute ME: Apoptotic effects of the tyrosine kinase inhibitor, masitinib mesylate, on canine osteosarcoma cells. Anticancer Drugs 24: 519-526, 2013.

53. Wolfesberger B, Tonar Z, Gerner W, Skalicky M, Heiduschka G, Egerbacher M, Thalhammer JG and Walter I: The tyrosine kinase inhibitor sorafenib decreases cell number and induces apoptosis in a canine osteosarcoma cell line. Res Vet Sci 88: 94-100, 2010. 